JOURNAL OF SECURITY AND SUSTAINABILITY ISSUES

ISSN 2029-7017 print/ISSN 2029-7025 online

2018 December Volume 8 Number 2

http://doi.org/10.9770/jssi.2018.8.2(12)

\title{
Scopus
}

\section{MUNICIPAL WASTE, AS CRITICAL INFRASTRUCTURE, MANAGEMENT: CASE OF LITHUANIA}

\author{
Andrejus Novikovas ${ }^{1}$, Andrius Stankevičius ${ }^{2}$ \\ 1,2 Mykolas Romeris University Ateities st. 20, LT-08303 Vilnius, Lithuania
}

Emails:andrejus@mruni.eu, stankevicius@mruni.eu

Received 20 February 2018; accepted 25 November 2018; published 30 December 2018

\begin{abstract}
With the changing global security situation, increase in external threats or emergence of new ones (cyberattacks, onconventional warfare models, etc.), countries must feel concern regarding consolidation of their security (e.g. Novikovas et al. 2017; Šišulák 2017). The fight against terrorism and the mitigation of climate change are key challenges facing global social changing. The issue of climate change is in synergy with the concepts of ecological, economic and energy security. Global development increasing demand of energy, triggered by increasing population and respective increase of economic activities, and consequent environmental degradation (Tvaronavičienè, 2016). Climate change and increasing human activities posing a serious threat to the ecological security in different fields ( $\mathrm{Li}$ et al. 2017). Terrorist attacks in the USA, floods in 2002, shaped new attention EU Institution to Critical Infrastructure (CI) concept, as an element of security. Critical infrastructure, as a phenomenon (for example energy), has become an argument in making political decisions (Tvaronavičienè, 2012). One of the ecological security elements is municipal waste management, which, as a business sector, is characterized as a complex phenomenon, which includes: infrastructure-engineering, administrative-functional, political and technological aspects. The aim of the topic is to analyze the municipal waste management sector as a phenomenon of national security. The topic reveals theoretical insights of the municipal waste management sector, identified it as a critical infrastructure object, in the context of Lithuanian national security. The object - peculiarities of legal regulation of critical infrastructure in EU and Lithuanian legal acts. The authors applied scientific methods such as document analysis, teleological, critical-analysis, comparative and generalization.
\end{abstract}

Keywords: municipal waste management; critical infrastructure; national security; ecological security; environmental protection; economic security

Reference to this paper should be made as follows: Novikovas, A.; Stankevičius, A. 2018. Municipal waste, as critical infrastructure, management: case of Lithuania, Journal Security and Sustainability Issues, 8(2): 257-265. http://doi.org/10.9770/jssi.2018.8.2(12)

JEL Classifications: F01

\section{Introduction}

The issue of climate change is closely related with issues of ecological, economic and energy security. Those are key elements, influencing sustainable development and security widely discussed in scientific literature (e.g. Lankauskienè, Tvaronavičienè, 2012; Tumalavičius, 2016; Tvaronavičienè, 2016) and law regulation. According to Communication from the Commission Europe 2020, „Climate and resource challenges require drastic action. Strong dependence on fossil fuels such as oil and inefficient use of raw materials expose our consumers and businesses to harmful and costly price shocks, threatening our economic security and contributing to climate change", COM (2010) 2020. According to The Treaty on the functioning of the European Union: „Environmental protection requirements must be integrated into the definition and implementation of the Union's policies and activities, in particular with a view to promoting sustainable development " (2012/C 326/01). The Constitution of the Republic of Lithuania rules: „The State shall take care of the protection of the natural environment, wildlife and plants, individual objects of nature, and areas of particular value, and shall 
supervise the sustainable use of natural resources, as well as their restoration and increase. The destruction of land and subsurface, the pollution of water and air, radioactive impact on the environment, as well as the depletion of wildlife and plants, shall be prohibited by law " (Official gazette. No. 33-1014, 1992).

The municipal waste management sector is one of the constituent elements in the environmental protection system. It is a public service, that involves the collection, transport, use, disposal, the organization of these activities, monitoring, and subsequent disposal of municipal waste (Republic of Lithuania Law on Waste Management). This sector is characterized by the specifics of legal regulation, institutional framework, competitiveness and technological development. The abundance of legal disputes and conflicts, the diversity of cases, the opinion of the Anticorruption Commission of the Seimas, that the Ministry of the Environment does not ensure control of the waste management sector, presuppose discussion to analyze interaction between municipal waste management sector and critical infrastructure in the context of the national security.

Authors discussed, that the critical infrastructure system has a dynamic, evolutionary character in the context of social change, which implies the need for continuous debate on identifying the economy, administration sector or service systems as part of the critical infrastructure system. As an example, we can propose US initiatives to identify the national electoral system as a critical part of the infrastructure: Department of Homeland Security has designated elections systems as part of our nation's critical infrastructure.

\section{The concept of critical infrastructure and its meaning in the EU and Lithuania law regulation.}

Infrastructure means the basic systems and services, such as transport and power supplies, that a country or organization uses in order to work effectively (Dictionary. Cambridge). In modern society, infrastructure system and its components do not exist in isolation and the functional or physical relationships between them are dynamic and complex. Due to interdependences inside the infrastructure or among infrastructures, the failure in any part of system will affect other parts or even spread and cause disturbances to other infrastructures through functional or physical connectivity (Coroiu, 2015). According to mentioned, the concept of critical infrastructure revealed through systematic, holistic analyze, providing a classification of these phenomenon. Main question, which must be answered - what makes infrastructure critical or what are the main criteria, conditions of this phenomenon? Authors would like to mention for comparative analysis the definition of CI according to legal regulation of USA, because this country dedicates a lot of attention to the analysis of this phenomenon, especially after the terrorist attacks in New York. Critical infrastructure- systems and assets, whether physical or virtual, so vital to the United States that the incapacity or destruction of such systems and assets would have a debilitating impact on security, national economic security, national public health or safety, or any combination of those matters (\$1016(e) of the USA Patriot Act of 2001 (42 U.S.C. §5195c(e))

Legal regulation of EU first time uses term CI in 2004. According to Communication from the Commission to the Council and the European Parliament (COM (2004) 702): critical infrastructures consist of those physical and information technology facilities, networks, services and assets which, if disrupted or destroyed, would have a serious impact on the health, safety, security or economic well-being of citizens or the effective functioning of governments in the Member States. First mentioned definition are more explicit, highlighting, ,systems and assets ", and its more adaptable for social changing and the dynamic nature of hazards.

Council Directive 2008/114/EC reveal definition of critical infrastructure more precise and explicitly. According to this document, it's possible to identify first classification of CI phenomena. The definition of critical infrastructure is distinguished in two sectors:

(a) Critical infrastructure' means an asset, system or part thereof located in Member States which is essential for the maintenance of vital societal functions, health, safety, security, economic or social well-being of people, and the disruption or destruction of which would have;

(b) 'European critical infrastructure' or 'ECI' means critical infrastructure located in Member States the disruption or destruction of which would have a significant impact on at least two Member States. The significance of the impact shall be assessed in terms of cross-cutting criteria. This includes effects resulting 
from cross-sector dependencies on other types of infrastructure;

Those definitions disclosure geographical (territorial) and sectorial interdependencies of the CI (for example pipelines stretch across continents, electric power, information network systems). Such geographic dislocation is determined by technological, functional, historical features. Especially are mentioned post- Soviet countries, whose economic development was based on the planned economy and the defense strategy of the USSR.

European Programme for Critical Infrastructure Protection develop these classification establishing ,external dimension". This provision primarily focusses on the EU's neighbors. The interconnected and interdependent nature of today's economy and society means that even a disruption outside of the EU's borders may have a serious impact on the Community and its Member States. Disruption or destruction of a critical infrastructure within the EU may have a detrimental effect on the EU's partners and its Member States (COM(2006) 786).

Dimensions:

1. External

2. Internal

2.1. Members state

2.2. EU

The same classification of CI is provided by Lithuanian legal acts. According to Republic of Lithuania civil security law (Official Gazette, No. 159-7207, 2009), object of national significance- state institution, enterprise, economy, energy, transport, telecommunications or other infrastructure, irrespective of its form of ownership, the control or functioning of which would disturb or threaten to cause significant damage to national security, would disturb state administration, economic systems, state-owned enterprises the functioning of the branch or infrastructure, or which may be selected as a target in the event of war, attacks or acts of terrorism and, as a result, become the focus of an emergency. The Resolution of the Government of the Republic of Lithuania No 943 rules: European Critical Infrastructure is an object of national significance in the Member States of the European Union the destruction or disruption of which would have a significant impact on at least two Member States (Official gazette. No. 105-4950, 2011).

To be mentioned, Lithuania does not establish a unified national strategy, which explicitly reveal the CI conception: state - institutional tasks and objectives, political-strategic approach. Many European countries already have quite advanced initiatives and real measures in this area. For example, The National Strategy for Critical Infrastructure Protection of Germany is the starting point for consolidating the achieved results so far and for further developing them in the face of new challenges.

It is noteworthy, Lithuanian law regulation reveals the definition of CI in different hierarchy of law acts. It can be formulated as a systemic weakness of the law.

Second classification of CI phenomena is based on type of security:

1) Economic security; 2) cyber security; 3) public security; 4) energy security; 5) ecological security; 6) health security 7) cultural- moral security.

Law on the Basics of National Security (Official Gazette, No. 2-16, 1997) mentioned, that Lithuanian national security policy shall consist of the provisions of the state foreign, defense, economic, public security, social, culture, health, environmental, educational and scientific as well as other state policy provisions aimed at ensuring national security. The first priorities of national security, which ensure the sustainability of state development, are economic, energy, environmental, information, cybernetics, and social security.

The third classification can be grouped according to the functional sector:

- Energy installations and networks (e.g. electrical power, oil and gas production, storage facilities and refineries, transmission and distribution system).

- Communications and Information Technology (e.g. telecommunications, broadcasting systems, software, hardware and networks including the Internet)

- Finance (e.g. banking, securities and investment)

- Health Care (e.g. hospitals, health care and blood supply facilities, laboratories and pharmaceuticals, search 
and rescue, emergency services)

- Food (e.g. safety, production means, wholesale distribution and food industry)

- Water (e.g. dams, storage, treatment and networks)

- Transport (e.g. airports, ports, intermodal facilities, railway and mass transit networks, traffic control systems)

- Production, storage and transport of dangerous goods (e.g. chemical, biological, radiological and nuclear materials)

- Government (e.g. critical services, facilities, information networks, assets and key national sites and monuments) (According to COM (2004) 702).

Law on the Protecting Important Objects for National Security (Official gazette, No. IX-1132, 2002) reveals strategically important economic sectors for ensuring national security: 1) energy; 2) transportation; 3) information technology and telecommunications, other high-tech;4) finance and credit; 5) military equipment. The fourth classification is based on analyzing criteria, which determining the factors, that make infrastructure as critical.

According to Directive 2008/114/EC and Communication from the Commission (COM (2006) 786), established provisions:

casualties criterion (assessed in terms of the potential number of fatalities or injuries);

(b) economic effects criterion (assessed in terms of the significance of economic loss and/or degradation of products or services; including potential environmental effects);

(c) public effects criterion (assessed in terms of the impact on public confidence, physical suffering and disruption of daily life; including the loss of essential services).

The disruption or destruction of a particular critical infrastructure will be rated by the extent of the geographic area which could be affected by its loss or unavailability (scope). Evaluating severity, the consequences of the disruption or destruction of a particular infrastructure will be assessed on the basis of:

- Public effect (number of population affected);

- Economic effect (significance of economic loss and/or degradation of products or services);

- Environmental effect;

- Political effects;

- Psychological effects;

- Public health consequences.

Additionally, one more criterion is to be mentioned is effects of time. This criterion ascertains at what point the loss of an element could have a serious impact (i.e. immediate, 24-48 hours, one week, other). (COM (2004) 702).

Another type (the fifth) of classification is possible by type of capital, which take part in business activity: a) private/public b) internal/external c) mixed.

\section{Municipal waste management and critical infrastructure}

The municipal waste management system is not directly identified as critical infrastructure in the EU legal framework.

Resolution No. 113 of the Republic of Lithuania Government "Procedures of establishment and recognition of the state importance objects of waste management" (Official gazette, No. 12-302, 2000), disclosure criteria, according to which state importance objects of waste manage sector are identified. Based on these criteria, two groups of state-owned waste management areas can be identified:

1) State importance objects of waste management sector. These are objects: manages more than one municipals waste management area; implementing waste reduction tasks in landfills (based on the State Waste Management Plan); ensures the uninterrupted handling of these waste streams. (For example UAB „Fortum Klaipeda“) 
2) Waste management objects, which use for energy production (cogeneration) after sorting municipal waste, with energy value. These are objects: manages more than one municipals waste management area; and 51 percent or more of the shares and the voting rights attached to such shares are owned by the State of Lithuania or the state-owned company; and after sorting remaining and unsuitable for recycling municipal waste with energy value is used for cogeneration; and implements the National Energy Independence Strategy approved by the Seimas of the Republic of Lithuania (Official gazette, No. XI-2133, 2012).

3) Attention is, however, to be focused on the fact, that according to new amendment of law on the Protecting Important Objects for National Security (Official gazette, No. IX-1132, new amendment from 01/03/2018), waste manage sector are not identified as critical infrastructure object. This document not completely emphasize ecological security concept, because not establish waste manage sector as strategically important sector of the economy. It determines legal uncertainty. The purpose of this document is to ensure that the assets and territory located in the protection zones of enterprises, installations and property important for ensuring national security (objects, assets and economic sectors), which are important for the security of the state, are protected from all risks which may pose a threat to national security interests factors and to eliminate the causes and conditions of the occurrence of such factors. On the one hand, municipal waste sector is defined as critical infrastructure, on the other, according to higher power act- not. It presupposes a discussion about the disposal of these objects (systems), the status of investors and other issues, affecting the public interest. Accentuate, law regulation of Lithuania obligated to establish provisions of National Progress Program 2014-2020: "In order to ensure the quality of utilities, it is necessary to reconcile the interests of the environment, economic and social development. These factors contribute to improving the quality of life and business competitiveness." (Official gazette, No. 144-7430, 2012).

Detecting the interaction between the waste management system and the critical infrastructure phenomenon, authors reveal the potential relation between these phenomena and identify possible systemic aspects. For example, the quality of the environment and economic development are the main blocks of sustainable development, the protection of which is of primary interest to the national security of the Republic of Lithuania. Also mentioned, that municipal waste sector has dual nature: in one hand is part of ecological security; and other - part of business. The aforementioned provisions presuppose the direction of research through the dimensions of ecological and economic security.

\section{Ecological security}

Ecosystem services have become one of the core elements of ecosystem management and evaluation. As a key area of ecosystem services and for maintaining national ecological security, ecosystem changes and implementation effect evaluation are important in national key ecological function zones, for promoting the main function zone strategy and for improving the construction of an ecological civilization (Zhai et al., 2018). As already mentioned, environmental protection is one of the main tasks enshrined in both EU and Lithuanian legislation. Directive 2004/35/CE of the European Parliament and of the Council on environmental liability with regard to the prevention and remedying of environmental damage, established: 'environmental damage' means: damage to protected species and natural habitats, which is any damage that has significant adverse effects on reaching or maintaining the favorable conservation status of such habitats or species. One of the activities is waste management: waste management operations, including the collection, transport, recovery and disposal of waste and hazardous waste, including the supervision of such operations and after-care of disposal sites, subject to permit or registration. Also mentioned, that waste management sector, as business sector includes transboundary shipment of waste within, into or out of the European Union, requiring an authorization or prohibited. The regional waste management system in Lithuania operates on the basis of the merger and cooperation of the counties (local municipalities). The purpose of this cooperation is to manage waste together and to avoid the negative impact of waste on public health and the environment. Mentioned, that municipal waste manage system consist of various elements of business activity such collection, transport, use, disposal, the organization of these activities, monitoring, and subsequent disposal of municipal waste. Mentioned each parts of the system must ensure prevention of the ecological event. 
On this basis, exist implementation of the waste management engineering system. Its disclosure interdependences of waste manage system: internal and external nature. Internal means, that all types of waste that are involved in waste management have a systemic nature. For example, hazardous or medical waste can penetrate into the flow of municipal waste, or definition what is municipal waste is actual object of discussion among lawyers and politicians. For example, wide or narrow definition of municipal waste content, affects the lifetime of objects (goods), the presence them in civil circulation and obliges authorities to ensure technological and engineering challenges in implementing the functioning of the waste management system. External nature reveals a holistic approach to systemic links between functional sectors. Disruption or destruction in waste manage system can determinate negative aspects in other sectors: water, health, government. Mentioned, waste management sector interacting with energy security: municipal waste is used for generating heat and electric power. Cybersecurity or electricity sectors influents waste management. Waste management sector must ensure adequate prevention of possible risks of internal or external factors, mentioned above, in the context of ecological safety. Its notable, that according to resolution No. 742 of the Republic of Lithuania Government (Register, No. 20862, 2016) "On the approval of the critical information infrastructure identification methodology", the significance of infrastructure object is assessed on the basis of these criteria for potential damage caused by destruction, damage to the infrastructure or malfunctioning of its infrastructure. One of these criteria- environmental damage. Determining interdependencies and cascading failure modes in critical infrastructures is a complex problem that is exacerbated further by the diverging characteristics of the interconnected infrastructure types (Svendsen et al., 2007). Inter-dependence is a major challenge for risk management in critical infrastructure. This is because economies and societies rely on interdependent and interconnected infrastructure systems. This gives rise inter alia to a phenomenon known as "cascading events" - that is, once one disruption occurs, others are likely to follow within systems and processes that are connected to the infrastructure affected by the initial disruption (OECD 2008).

\section{Economic security}

Rapid economic development has led to increasing threats to the environmental security and regional sustainable development (Wang Delu 2017). Economies of countries are not homogeneous, they are characterized by different economic structures and different their transformation patterns (Tvaronavičienė, 2014). Effective functioning of social economy affects the provision of economic security (Menshikov et al., 2017). Economic security could be considered as a preparation state of the economy for ensuring decent conditions for living and developing the personality, the social-economic stability and the political military capability of the society and the country in order to eliminate internal and external threats (Huber et al., 2010, Filipishyna et al., 2018; Mishenin et al, 2018; Volchik et al., 2018). It is a systematic phenomenon that is influenced by many factors. Firstly, bureaucracy, overregulation, non-transparent, non-integrity lobbying activity presupposes monopoly and unfair competitive threats (Stankevičius, Lukšaite, 2016; Finogentova et al., 2018). Secondly, competitive activity can result threats to economic security, which is an important component of the country's security (Stankevičius et al. 2015; Kuril, 2018). Thirdly, the shadow economy has an impact on all economic phenomena and processes of the society: formation and distribution of income, and, of course, economic growth and sustainable development in general (Tvaronavičienè, 2014; Caurkubule, Rubanovskis, 2014; Luzgina, 2017). The Constitutional Court of the Republic of Lithuania, analyzing competition law regulation issues in the sphere of waste management services, ruled: under the Constitution, municipalities, while acting freely and independently within their competence defined by the laws regulating economic activity (inter alia, waste management), are bound by the principles forming the constitutional basis of the economy of this country, as well as by other constitutional imperatives. This means that, in the area of waste management, municipalities must pay heed to the requirement, as implied by the constitutional imperative of fair competition, that waste managers must be selected by means of a tender according to their capability to provide uninterrupted, good quality, and accessible services (Case No. 44/2011). Competition Council of the Republic of Lithuania declared the violations of competitiveness in the field of municipal waste management in many Lithuanian municipalities, some of them, for example, Kaunas municipality, do not ensure the implementation of the principle of competitiveness from 2002 to the present (Resolution No. 2S-27). Competitiveness phenomena are 
interacting with another's negative elements, like shadow economy, corruption. Attention is, however, to be focused on the fact, that these elements are objects of another type of security-public security. Public security is part of national security that includes the protection of the legitimate interests of the human being, the society and the state from criminal acts and other violations of law, natural or man-made disasters (Public Security Program 2015-2025, 2015).

In the context of globalization, the identification of critical infrastructure objects requires the use of an integrated (holistic) approach that includes geographic, systemic economic, ecological, energy, cybernetic aspects. These must ensure protection, safety and security of critical infrastructures.

\section{Conclusions}

Visualization of classification makes it possible to identify objects, systems as critical infrastructure. Based on this classification, the municipal waste sector is identified as a critical infrastructure, especially in area of ecological security, public and economic security. Ecological and economic security are basic elements, which reveals objects as a critical infrastructure, highlighting their dynamic nature in the context of globalization.

It is also to be mentioned, that the interaction between ecological and economic security is the key blocks of sustainable development, which form the provisions of the Lithuanian strategic programs (For example, National Progress Program of Lithuania (Resolution No. 1482 of the Republic of Lithuania Government "On the approval of the national progres program for the 2014-2020“). Mentioned, that municipal waste managing sector may have interdependencies manifestations with another kind of critical infrastructure objects and others sectors: cyber security, energy security; water, health, government.

The municipal waste management sector as a critical infrastructure element in the legal regulation of the Republic of Lithuania is ambiguous. The authors identify the contradictions of the systemic nature of legal acts, the inaccuracies of definitions and the demand to embed national strategy for critical infrastructure protection. Authors argue, that the subject of these areas should be analyzed in further triangular investigations.

\section{References}

Caurkubule Ž.; Rubanovskis A. 2014. Shadow economy as an obstacle to sustainable Economic development, Journal of Security and Sustainability Issues 4(1): 175-186. http://dx.doi.org/10.9770/jssi.2014.4.2(6)

Communication from the Commission EUROPE 2020. A strategy for smart, sustainable and inclusive growth. COM (2010) 2020.

Communication from the Commission on a European Programme for Critical Infrastructure Protection. COM (2006) 786.

Communication from the Commission to the Council and the European Parliament Critical Infrastructure Protection in the fight against terrorism. COM (2004) 702 .

Competition Council of the Republic of Lithuania, Resolution No. 2S-27. Official gazzete. 2008, No. 99-1337.

Constitutional Court of the Republic of Lithuania, Case No. 44/2011, Ruling, 5 March 2015, No. KT9-N5/2015. TAR, 2015-03-05, Nr. 3412. Available on the Internet:

Coroiu, V. 2015. European Critical Infrastructures. European journal of public order and national security. 6(2): 11-19.

Council Directive 2008/114/EC of 8 December 2008 on the identification and designation of European critical infrastructures and the assessment of the need to improve their protection.

Directive of the European Parliament and of the Council of 21 April 2004, On environmental liability with regard to the prevention and remedying of environmental damage (2004/35/CE).

Filipishyna, L.; Bessonova, S.; Venckeviciute, G. 2018. Integral assessment of developmental stability: cases of Lithuania and Ukraine, Entrepreneurship and Sustainability Issues 6(1): 87-99. https://doi.org/10.9770/jesi.2018.6.1(7) 
Finogentova, O.; Tokarev, V.; Petrenko, M.; Primak, T. 2018. Acceptance criterion of state coercion in contemporary society, Entrepreneurship and Sustainability Issues 6(2): 830-839. http://doi.org/10.9770/jesi.2018.6.2(24)

Huber, G.; Rehm, P.; Schlesinger, M.; Valletta, R. 2010. Economic Security at Risk: Findings from the Economic Security Index.

Kuril, J. 2018. Public administration for safe and secure environment: case of Slovak Republic, Entrepreneurship and Sustainability Issues 5(3): 493-501. https://doi.org/10.9770/jesi.2018.5.3(6)

Lankauskienè, T.; Tvaronavičienè, M. 2012. Security and sustainable development approaches and dimensions in the globalization context. Journal of Security and Sustainability Issues 1(4): 287-297. http://dx.doi.org/10.9770/jssi.2012.1.4(5)

Li, HD (Li, Haidong); Gao, YY (Gao, Yuanyun); Li, YK (Li, Yingkui); Yan, SG (Yan, Shouguang); Xu, YY (Xu, Yuyue). 2017. Dynamic of Dalinor Lakes in the Inner Mongolian Plateau and Its Driving Factors during 1976-2015. Water 9 (10) Article Number: 749 http:// dx.doi.org/10.3390/w9100749

Lietuvos Respublikos atlieku tvarkymo įstatymas (suvestinè redakcija nuo 2018-01-24) [Republic of Lithuania Law on Waste Management]. Official gazette. 1998. No. 61-1726.

Lietuvos Respublikos civilinès saugos įstatymas (suvestinè redakcija nuo 2017-11-01) [The Republic of Lithuania civil security law (consolidated version since 01-11-2017)]. Official gazette. 1998, No. 115-3230.

Lietuvos Respublikos Konstitucija. [The Constitution of the Republic of Lithuania]. Official gazette. 1992, No. 33-1014.

Lietuvos Respublikos nacionalinio saugumo pagrindų ịstatymas (suvestinė redakcija nuo 2014-10-29) [Republic of Lithuania Law on the Basics of the National Security (consolidated version since 29-10-2014)]. Official gazette. 1997, No. 2-16.

Lietuvos Respublikos Seimo nutarimas "Dèl viešojo saugumo plètros 2015-2025 metu programos patvirtinimo" [Public Security Program 2015-2020]. TAR, Nr. 7293, 2015-05-13.

Lietuvos Respublikos strateginę reikšmę nacionaliniam saugumui turinčių įmonių ir įrenginių bei kitų nacionaliniam saugumui užtikrinti svarbių įmonių įstatymas (suvestinè redakcija nuo 2018-03-01) [ Act of the Republic of Lithuania strategic value for national security companies and equipment and other national security for important companies (consolidated version since 01-03-2018)]. Official gazette. 2002, No. 103-4603.

Lietuvos Respublikos Vyriausybės 2000 m. vasario 2 d nutarimas Nr. 113 "Dėl valstybinès reikšmės atliekų tvarkymo objektų steigimo ir pripažinimo tvarkos aprašo patvirtinimo" [Resolution No. 113 of the Republic of Lithuania Government "Procedures of establishment and recognition of the state importance objects of waste management”] Official gazette, No. 12-302, 2000).

Lietuvos Respublikos Vyriausybès 2016 m. liepos 20 d. nutarimas Nr. 742 "Dèl ypatingos svarbos informacinės infrastruktūros identifikavimo metodikos patvirtinimo" [Resoliution No. 742 of the Republic of Lithuania Government of 20 July 2016 "On the Approval of the Critical Information Infrastructure Identification Methodology"]. TAR, 2016-07-21, Nr. 20862.

Lietuvos Respublikos Vyriausybès Nutarimas Nr. 1482 "Dėl 2014-2020 metų nacionalinès pažangos programos patvirtinimo" [Resolution No. 1482 of the Republic of Lithuania Government "On the approval of the national progres program for the 2014-2020"] Official gazette, No. 144-7430, 2012.

Lietuvos Respublikos Vyriausybès nutarimas Nr. 943 "Dèl Europos ypatingos svarbos infrastruktūros objektų nustatymo, priskyrimo šiems objektams ir jų saugumui užtikrinti būtinų priemonių parengimo tvarkos aprašo patvirtinimo" [The Resolution of the Government of the Republic of Lithuania "Approval of the description of the procedure for the establishment of the European Critical Infrastructure, their attribution to these facilities and the procedures necessary for their safety"]. Official gazette. 2011, No. 105-4950.

Luzgina, A. 2017. Problems of corruption and tax evasion in construction sector in Belarus, Entrepreneurship and Sustainability Issues 5(2): 263-282. https://doi.org/10.9770/jesi.2017.5.2(8)

Menshikov V.; Volkova O.; Stukalo N.; Simakhova A. 2017. Social economy as a tool to ensure national security, Journal of Security and Sustainability Issues 7(1): 211-231. https://doi.org/10.9770/jssi.2017.7.2(4)

Mishenin, Y.; Koblianska, I.; Medvid, V.; Maistrenko, Y. 2018. Sustainable regional development policy formation: role of industrial ecology and logistics, Entrepreneurship and Sustainability Issues 6(1): 329-341. https://doi.org/10.9770/jesi.2018.6.1(20)

National Energy Independence Strategy approved by the Seimas of the Republic of Lithuania. Official gazette, No. XI-2133, 2012.

Novikovas, A.; Novikovienè, 1.; Shapoval, R.; Solntseva, K. 2017. The peculiarities of motivation and organization of civil defense service in Lithuania and Ukraine, Journal of Security and Sustainability Issues, 7(2): 369-380. http://dx.doi.org/10.9770/jssi.2017.7.2(16) 
OECD. 2008. Protection of 'critical infrastructure' and the role of investment policies relating to national security.

Šišulák, S. 2017. Userfocus - tool for criminality control of social networks at both the local and international level, Entrepreneurship and Sustainability Issues 5(2): 297-314. https://doi.org/10.9770/jesi.2017.5.2(10)

Stankevičius, A.; Lukšaitè, A. 2016. Transparent lobbying for sustainability: case of Lithuania. Entrepreneurship and Sustainability Issues 4(2): 220-227. http://jssidoi.org/jesi/article/99

Stankevičius, A.; Simanavičienè, Ž. (2015). Economic security and national competitiveness. Public security and public order. MRU. 2015 (15): 126-144.

Svendsen N K,; Wolthusen S D. Connectivity models of interdependency in mixed-type critical infrastructure networks. Information Security Technical Report. 2007, (12): 44-55.

Treaty on the functioning of the European Union. (2012/C 326/01). Available on the Internet: < http://eur-lex.europa.eu/legal-content/ EN/TXT/?uri=celex\%3A12012E\%2FTXT>

Tumalavičius, V. 2016. Security of Society in Lithuania: Concept and Scientific Fundamentals in its Ensuring. Sociālo Zinātņu Vēstnesis. 1(22): 92-118 p.

Tvaronavičienè, M. 2012. Contemporary perceptions of energy security: policy implications, Journal of Security and Sustainability Issues 1(4): 235-247. http://dx.doi.org/10.9770/jssi.2012.1.4(1)

Tvaronavičienė, M. 2014. If industrial sector development is sustainable: Lithuania compared to the EU, Entrepreneurship and Sustainability Issues 1(3): 134-142. https://doi.org/10.9770/jesi.2014.1.3(2)

Tvaronavičienė, M. 2016. Entrepreneurship and energy consumption patterns: case of households in selected countries, Entrepreneurship and Sustainability Issues 4(1): 74-82. https://doi.org/10.9770/jesi.2016.4.1(7).

USA Election Assistance Commission https://www.eac.gov/election-officials/elections-critical-infrastructure/ USA Patriot Act of 2001 (42 U.S.C. $\$ 5195 \mathrm{c}(\mathrm{e}))$.

Volchik, V.; Klimenko, L.; Posukhova, O. 2018. Socio-economic sustainable development and the precariat: a case study of three Russian cities, Entrepreneurship and Sustainability Issues 6(1): 411-428. https://doi.org/10.9770/jesi.2018.6.1(25)

Wang, CY (Wang Chunye); Delu, P (Delu, Pan) 2017. Zoning of Hangzhou Bay ecological red line using GIS-based multi-criteria decision analysis. Ocean \& coastal management 139: 42-50. https://doi.org/10.1016/j.ocecoaman.2017.01.013

Zhai, J; Hou, P.; Cao, W; Yang, M; Cai, MY; Li, J. 2018. Ecosystem assessment and protection effectiveness of a tropical rainforest region in Hainan Island, China, Journal of geographical sciences 4(28): 415-428. https://doi.org/10.1007/s11442-018-1481-1 